UCRL- 92025

\title{
PREPRINT
}

DLNF- $\times 50310-70$

\section{Qualitative Comparisons of Fusion Reactor Materials for Waste Handling and Disposal}

\section{R. Carroll Maninger}

This paper was prepared for submittal to the

6th Topical Meeting oin the Technology of

Fusion Energy, San Francisco, CA

March 3-7, 1985.

Apri1 8, 1985

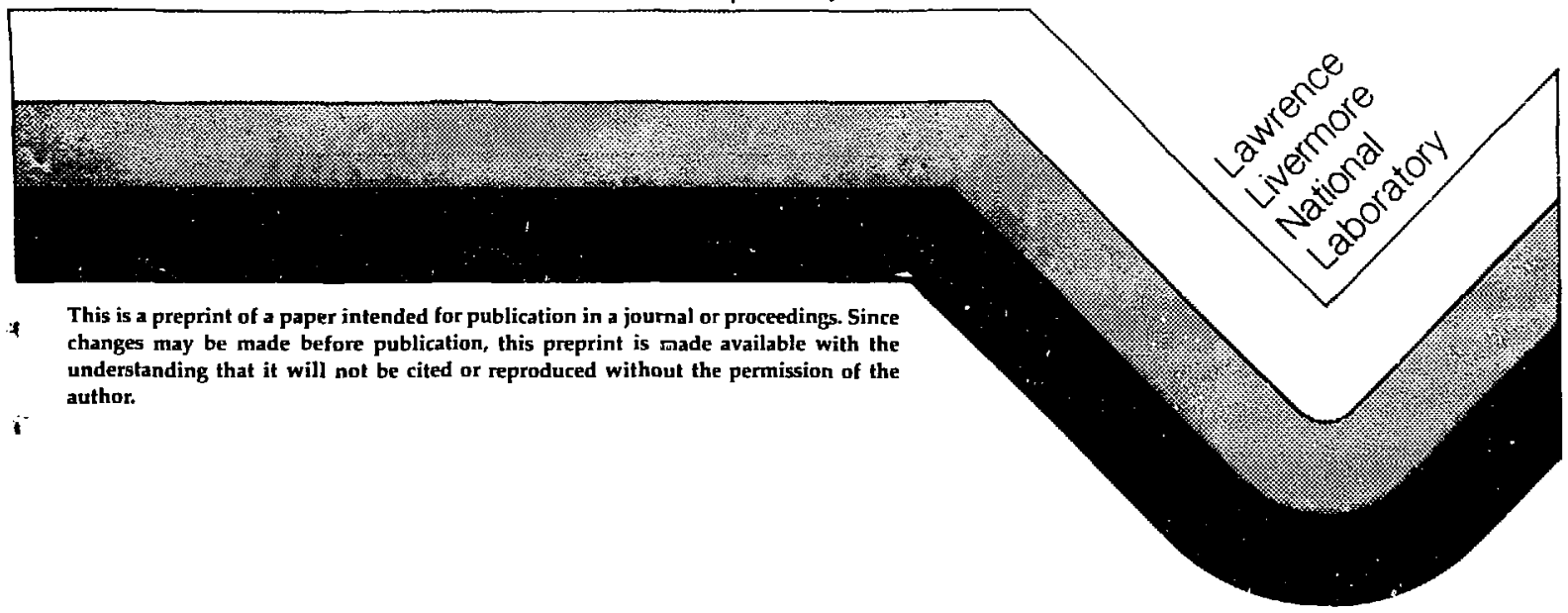

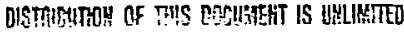

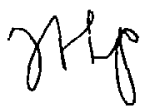




\author{
R. Carroll Maninger, Lawrence Livermore National Laboratory \\ P.O. Box 5511, L-644 \\ Livermore, CA 94550
}

(415) 422-6905

\section{ABSTRACT}

The activation of five structural materials and seven coolant/breeder/multiplier materials in a common reference neutron enviromment was calculated with the FORIG activation code. The reference environment was the neutron flux and spectrum at the first wall of the mirror advanced reactor study (MARS) reactor. Qualitarive comparison of these activated materials were made with respect to worker protection requirements for gamma radiation in handling the materials and with respect to their classifications for near-surface disposal of radioactive waste.

\section{INTRODUCTION}

The activation of the materials in fusion reactors is the key to remote handling requirements for waste, to processing and disposal methods for waste, and to accident severity in waste management operations. 1-4 In order to realize the desirable environmental potentials of fusion power systems, there are at least three major goals for waste management. These goals are (a) near-surface burial; (b) on-site disposal of the fusion reactor; (c) acceptable radiation doses at the least cost during and after waste management operations.

Although meeting the aboie goals will depend finally on the specific reactor designs and on the specific materials chosen for the blankets, early design guidance can be provided by qualitative comparisone of blanket materials under a standard set of concitions. In Ref. 5, the conclusion states that "...all fusion reactors, regardless of geomerric shape and first wall radius, having unprotected first walls made of similar material and operated for the same amount of time, will have roughly equal total radioactiviti: s,

\footnotetext{
Work performed under the auspices of the U.S. Department of Energy by the Lawrence Livermore National Laboratory under contract number $W-7405-E N G-48$.
}

adjusted only in proportion to the product of their thermal power and their first wall thickness." This concluaion allows the use of a standard fusion-reactor reference configuration to investigate qualitative comparisons of materials with respect to properties dependent on radioactivicy from activation in the first wall zone. Extensions of results to specific reactor designs is then only a mater of scaling based on thermal power and first wall thickness for blanket/first wall materials.

For this study, the reference neutron environment (flux and spectrum) is the first wall zone of MARS $^{6}$ with a $4.1 \mathrm{mw} / \mathrm{m}^{2}$ wall loading, a first wall thickness of $0.003 \mathrm{~m}$, and a two year exposure time. The neutron flux and spectrum vere the same for all the materials. They were calculated with TART specifically for the first wall of the MARS blanket. This blanket consists of HT 9 for structural material and $17 \mathrm{LiB3} \mathrm{Pb}$ for the coolant/breeder material. The spectra for other combinations of blanket materials would be different, but the integrated values of cross sections would be roughly the same for all combinations. Thus, qualitative comparisons of materials, as opposed to evaluations of detailed design differences among blankets, will be roughly independent of materials combinations in the first wall where $24 \mathrm{MeV}$ neutrons dominate. The reference compositions of materials for this study are shown in Table $I$.

The comparisons of these materials are based on the Remote Maintenance Rating (RMR) and the Waste Disposal Rating (WDR). 7, 0 The RMR is an index that gives a measure of the gamma-ray contact dose at the surface of a thick infinite slab of activased material. The slab is considered thick when the thickness dimenaion is several mean free paths of the gamma rays. As described in Ref. 7, the RMR can be converted to contact doses for small spheres or thin sheets by multiplying the RMR by a factor containing the ratio of the radius of the sphere or thickness of the 
sheet to the mean free path of the gamma rays in the materiale. However, such conversions will not change the relative ordering of qualitative comparison of materials. The units of the RMR are mrem/hr. If the RMR is less than $2.5 \mathrm{mrem} / \mathrm{hr}$, workers can be in contact with the material without any special protection for gamma radiation. However, because the RHR is defined here only for gamma radiation, there is still the possibility that protection may be needed for inhalation and ingestion of alpha and beta emitters. This is in accordance with the NRC 10CFR20 regulations on worker safety.9 As the RMR becomes greater and greater than $2.5 \mathrm{mrem} / \mathrm{hr}$, more and more protection against contact and exposure is needed in the form of gamma shielding and/or use of remote handling equipment.

The WDR is an index that gives a measure for classifying wastes in accordance with the NRC 1OCFR61 regulation on licessing requirements for land disposal of radioactive wastes. 10 The WDR is defined as follows:

$$
\text { WDR }=\sum_{i} c(i) / L(i),
$$

where $C(i)$ is the concentration of the $i t h$ radionuclide in the waste material $\left(\mathrm{Ci} / \mathrm{m}^{3}\right)$ and $\mathrm{L}(\mathrm{i})$ is the corresponding allowable concentration limit for a given waste class as provided in 10CFR61. The intent of 10CFR6 1 is to protect inadvertent intruders at disposal sites from radiation doses greater than $500 \mathrm{mrem} /$ year. 10,11 The radionuclides explicitly covered by limits in 10CFR61 (show in Table II-A) are appropriate for waste classification of fission products, fission reactor activation products, and transuranics. However, in fusion there are other nuclides (especially long-lived gamma emitters) that must be considered explicitly to ensure limiting doses to inadvertent intruders to $500 \mathrm{mrem} /$ year or less. Additional nuclides of this type are shown in Table II-B. 12

For alloys and mixtures of materials, near-burface land disposal can be used when WDR $=<1$. If WDR $>1$, the materials are not suitable for near-surface disposal without some kind of processing to reduce the WDR to 1 or less. This processing may be simple dilution with inert materials in the waste package so that the WDR of the radionuclides averaged over the total volume of the package is less than 1.

The RMR and WDR are calculated from activation product concentrations obtained with the Lawrence Livermore National Laboratory (LLNL) computer codes TARTNP, 13 ORLIB, 14 ACTL, 15 and FORIG. 16 The data inputs are the reference neutron environment
(MARS) and the materials compositions listed in Table $I$.

\section{QUALITATIVE COMPARISONS OF REMOTE MAINTENANCE RATINGS}

The relative rankings by RMR for blanket materials considered in this study are shown in Table III for various times after removal from the neutron flux. Inspection of Table II I reveals that there are spreads among the materials of four to six orders of magnitude in the RMR at a given time after shutdown with the greatest spreads at the later times. Also, the relative rankings of materials change from one time to another. Depending upon the material, the RMR dro'ss four to nine orders of magnitude from the 1-hour to 100year time for that material. Uniy the RMR for $\mathrm{Li}_{2} \mathrm{O}$, FLIBE, and lithium drop enough for the materials to be handled without worker protection at 100 years. However, even these materials require worker protection at 10 years or less for large hodies of the materials or for close contact with components made with the materials. The degree of protection needed will depend on specific dimensions of components as well as on the material, but the RMR can be helpful in assessing the consequences of materials selection early in the design phase of a reactor and in planning waste disposal.

The major radionuclides contributing to the RMR for the materials at various times are shown in Table IV. Many of these are activation products of elements that are impurities in the materials. Thus, it is important to consider carefully the purity of materials to control costs of remote handling and shielding. The task of detailed identification of the sources (essential or impurity elements) is beyond the scope of this study. In general, Co60 is an undesirable component in all of the materials at 10 years. It originates mainly from cobalt, nickel, and copper. Therefore, if these elements are impurities, they should be carefully controlled if significant materials handling is expected at 10 years (say for waste processing). For 1-hour and 1-day times, $\mathrm{Na} 22$ and $\mathrm{Na2}$, are prominent nuclides in the breeding/multiplier materials and must be carefully considered if they come from impurities like elemental sodium or magnesium. (Nitrate salt has a high sodium content as an essential element.) Both breeding/multiplier and structural materials contain MnS4 and Mn56 as major contributors to RMR at early times. In both cases, these two nuclides come from natural elemental manganese and iron.

At 100 years, the prominent radionuclides are $A 126, \mathrm{Co60}, \mathrm{Nb} 94, \mathrm{Ag} 108 \mathrm{~m}, \mathrm{Bi} 207$, and Bi208. Except for $\mathrm{LiAlO}_{2}$, which has aluminum 
as an essential element, the A126 content of the materials can perhaps be controlled to reduce RMR. The No94 comes from molybdenum and niobium and can be controlled only to the extent that it is possible to control these two elements. The Ag108m comes from elemental silver, which appears to be an impurity and as such should be reduced as much as possible consistent with costs for shielding and handling. The bismuth nuclides come from bismuth and lead. Thus, Bi207 and Bi208 will always be generated in the LiPb breeding/ multiplier; control of bismuth as an impurity can reduce but not eliminate the bismuth gamma emitters.

\section{QUALITATIVE COMPARISONS OF WASTE DISPOSAL FATINGS}

The WDR at 10 years after shutdown for the materials of interest to the blanket comparison and selection study (BCSS) are displayed in Table $v$. The ratings for individual nuclides are shown as well as for subtotals of nuclides grouped according to Table II. Note th-contributions of the supplemental nuclides in Table. II-B to the total WDR for $\mathrm{LiAlO}_{2}, \mathrm{LiPb}$, TENELON, and ModHT9. The supplemental nuclides increase the WDR to values greater than 1 for each of these materials. Thus, they are significant factors in determining suitabilicy for near-surface disposal of $\mathrm{LiAlO}_{2}, \mathrm{LiPb}$, TENELON, and ModHT9.

Upon consideration of the WDR in Table $\mathrm{V}$ and the 10CFR61 regulations, the suitability of materials for near-surface disposal can be summarized as shown in Table VI. Column $I$ indicates that beryllium, $\mathrm{Li}_{2} \mathrm{O}, \mathrm{lithium}$, and FLIBE are well within the limits for near-surface disposal. However, at 10 years or less after removal from a reactor, all of these materials in intact packages would require worker protection during handling. At 100 years, the : ist three would not require protection, but oeryllium would still be too hazardous to handle without protection even though it can be disposed near-surface burial. All of the materials in column 1 are breeding/multiplier materials.

The alloys in column 2 are structural materials whose WDR are greater than 1 , but it is expected that, when they are packaged with other inert and less active materials from a reactor, the WDR integrated over the volume of the waste package will be less than 1 and near-surface disposal is permissible. Again, however, worker protection will be required even at 100 years because of the high RMR of intact waste packages.
The materials in column 3 have values for WDR too high to be reduced by simple dilution. Therefore, they must be processed in some way to remove the highly active components for near-surface burial of the bulk of the materials. The high activity components would then need to be disposed of as high level waste as suggested in footnote (c) of Table VI.

The major nuclides preventing near-surface disposal of materials in column 3 are listed in Table VII. The limiting source eiements for $\mathrm{LiAlO}_{2}$ and nitrate salt are essential to the composition of the materials and cannot be reduced or eliminated. The WDR for HT9, PCA, and $\mathrm{LiPb}$ can be reduced by reducing the amounts of the indicated source nuclides.

Activation and subsequent decay chains in lead and in lead with bismuth impurities produce several alpha-emitting nuclides (see Table VIII). These may cause safety problems in accident and materials handing scenarios for inhalation and ingestion. For waste management under the current 10GFR61, none of these nuclides would be limited for nearsurface burial because only transuranic nuclides are explicitly covered. If 10CFR61 is modified to cover any alpha-emitting nuslide with an effective half life greater than five years, then $\mathrm{Pb} 210, \mathrm{Bi} 210 \mathrm{~m}$, and $\mathrm{Po} 210$ may have limits. However, if the 1 is it is 100 $\mathrm{nCi} / \mathrm{g}$ (the current leve: for transuranic alpha emitters), there would still be no problem for waste disposal because the concentrations predicted for MARS are much less than $100 \mathrm{nCi} / \mathrm{g}$ for all the alpha emitters at 10 years after shutdown as shown in Table VIII.

\section{REFERENCES}

1. Background Information and Technical Basis for Assessment of Environmental Implications of Magnetic Fusion Energy, U.S. Department of Energy, DOE/ER-0170, August 1983.

2. S. Vogler, et al., Materials Recycle and Waste Management in Fusion Power Reactors - Progress Report for 1982, Argonne National Laboratory, Argonne, IL, ANL/FPP/TM-163 (Jan 1983).

3. S. Vogler, et al., "Waste Management of First Wall and Blanket Structural Materials for Tokamak Fusion Reactors," Nuclear Technology /Fusion, Vol. 4, PP. 415-420 (Sept. 1983).

4. J. A. Blink and G. P. Lasche, "The Influence of steel 1 .hpe on the Activation and Decay of Fusion Reactor First Wal1s," Nuclear Technology/Fusion, Vol . 4, pp. 1146-1151 (Sept. 1983). 
5. G. P. Lasche and J. A. Blink, "The Dependence of Neutron-Induced Radioactivity in Fusion Reactors on Geometric Design Parameters," Nuclear Technology/Fusion, Vol. 4, Pp. $\overline{823-828}$ (Sept. 1983).

6. B. G. Logan, et al., Mirror Advanced Reactor Study (MARS) Final Report," Lawrence Livermore National Laboratory, Livermore, CA, UCRL-53480 (1984).

7. D. W. Dorn and R. C. Maninger, "Issues in Radioactivity for Fusion Energy: Remote Maintenance Rating," Proc. of the IEEE 10th Symposium on Fusion Engineering, Philadelphia, PA, Dec, 5-9, 1983.

8. R. C. Maninger and D. W. Dorn, "Issues in Radioactive Waste Management for Fusion Power," IEEE Transactions on Nuclear Science, NS-30, (1), Pp. 571-576 (Feb. 1983).

9. Code of Federal Regulations, 10CFR Part 20, "Standards for Protection Agajinst Radiation."

10. (a) Draft Environmental Impact Statement on 10CFR61, "Licensing Requirements for Land Disposal of Radioactive Waste," NUREG-0782 (4 volumes) (Sept. 1981). (b) Final Environmental Impact Statement on 10CFR Part 61, "Licensing Requirements for Land Disposal of Radioactive Waste," NUREG-0945 ( 3 volumes) (Nov. 1982).
11. J. A. Blink, D. W. Dorn, and R. C. Maninger, "Disposal of Activated Fusion Wall Materials," Journal of Nuclear Materials, 122 and 123 (1984) 977-981, North Holland, Amsterdam.

12. R. C. Maninger and D. W. Dorn, Radiation Safecy Criteria for Maintenance and Waste Management in the Mirror Advanced Reactor Study, Lawrence Livermore National Laboratory, Livermore, CA, UCRL 90385, Revision 1 (1984).

13 E. F. Plechaty and J. R. Kimlinger, TARTNP: A Coupled Neutron-Phot on Monte Carlo Transport Code, Lawrence Livermore National Laboratory, Livermore, CA, UCRL-50400, Vol. 14 (1976).

14. J. A. Blink, R. E. Dye, and J. R. Kimlinger, ORLIB: A Computer Code That Produces One-Energy Group, Time, and Spatially Averaged Neutron Cross Sections, Lawrence Livermore National Laboratory, Livermore, CA, UCRL-53262 (1981).

15. M. A. Gardner and R. J. Howerton, ACTL: Evaluated Neutron Activation CrossSection Library-Evaluation Techniques and Reaction Index, Lawrence Livermore National Laboratory, Livermore, CA, UCRL-50400, Vol. 18 (1978).

16. J. A. Blink, FORIG: A Modification of the ORIGEN2 Isotope Generation and Depletion Code for Fusion Problems, Lawrence Livermore National Laboratory, Livermore, CA, UCRL-53263 (I982). 
Table 1-A. Elemental compositions.

\begin{tabular}{|c|c|c|c|c|c|c|}
\hline \multirow[b]{2}{*}{$z-4$} & \multirow[b]{2}{*}{ Element } & \multicolumn{5}{|c|}{ Structural geterials } \\
\hline & & $\begin{array}{c}\text { PCA } \\
(w t z)\end{array}$ & $\begin{array}{c}\text { VISCESTi } \\
(v(x)\end{array}$ & $\begin{array}{l}\text { HT-9 } \\
(y t z)\end{array}$ & $\begin{array}{l}\text { Modified } \\
\text { HT }-9 \\
(\text { Ut } \bar{x})\end{array}$ & $\begin{array}{c}\text { TENELON } \\
\text { Fe } 1518 \\
\text { (utz) }\end{array}$ \\
\hline $\begin{array}{l}3 \\
4\end{array}$ & $\begin{array}{l}\mathrm{Li} \\
\mathrm{Be}\end{array}$ & & & & & \\
\hline 5 & $\mathrm{~B}$ & 0.005 & & 0.01 & 0.001 & 0.002 \\
\hline $\begin{array}{l}6 \\
7\end{array}$ & $\begin{array}{l}\mathrm{C} \\
\mathrm{N}\end{array}$ & $\begin{array}{l}0.005 \\
0.01\end{array}$ & $\begin{array}{l}0.005 \\
0.01\end{array}$ & $\begin{array}{l}0.2 \\
0.05\end{array}$ & $\begin{array}{l}0.15 \\
0.001\end{array}$ & $\begin{array}{l}0.15 \\
0.005\end{array}$ \\
\hline 8 & 0 & & 0.01 & 0.01 & 0.007 & 0.007 \\
\hline 9 & $k$ & & & & & \\
\hline 11 & $\mathrm{Na}$ & & & & & \\
\hline 12 & $\mathrm{Hg}$ & & & & & \\
\hline 13 & Al & 0.03 & 0.02 & 0.01 & 0.002 & 0.008 \\
\hline 14 & $\mathrm{Si}$ & 0.5 & 0.03 & 0.35 & 0.2 & 0.2 \\
\hline 15 & $P$ & 0.01 & 0.003 & 0.02 & 0.013 & 0.013 \\
\hline $\begin{array}{l}16 \\
27\end{array}$ & $\begin{array}{l}5 \\
c_{1}\end{array}$ & 0.005 & $\begin{array}{l}0.001 \\
0.0001\end{array}$ & 0.02 & 0.004 & 0.004 \\
\hline $\begin{array}{l}19 \\
20\end{array}$ & $\begin{array}{l}\mathrm{K} \\
\mathrm{Ca}\end{array}$ & 0.0003 & 0.00001 & 0.0003 & 0.0003 & 0.0003 \\
\hline 22 & $\mathbf{T i}$ & 0.30 & 5.0 & 0.09 & 0.1 & 0.003 \\
\hline 23 & $v$ & 0.10 & 79.80 & 0.3 & 0.3 & 0.002 \\
\hline 24 & $C_{\boldsymbol{I}}$ & 14.0 & 15.0 & 12.0 & 11.0 & 15.0 \\
\hline $\begin{array}{l}25 \\
26\end{array}$ & $\begin{array}{l}\mathrm{Mn} \\
\mathrm{Fe}\end{array}$ & $\begin{array}{l}2.0 \\
64.88\end{array}$ & 0.004 & $\begin{array}{l}0.55 \\
85.0\end{array}$ & $\begin{array}{l}0.53 \\
\text { Balance }\end{array}$ & $\begin{array}{l}\text { 15.0 } \\
\text { Balance }\end{array}$ \\
\hline 27 & Co & 0.03 & & 0.02 & 0.005 & 0.005 \\
\hline 28 & $\mathrm{Hi}$ & 16.0 & 0.0004 & 0.5 & 0.006 & 0.006 \\
\hline $\begin{array}{l}29 \\
30\end{array}$ & Cu & 0.02 & 0.0002 & 0.09 & 0.003 & 0.003 \\
\hline 33 & As & 0.02 & 0.0002 & & & \\
\hline 38 & $\mathbf{S r}$ & & & & & \\
\hline 40 & $\mathrm{Zr}$ & 0.005 & & 0.001 & 0.001 & 0.001 \\
\hline 41 & $\mathrm{Nb}$ & 0.03 & 0.0004 & 0.11 & 0.00011 & 0.00011 \\
\hline 42 & Mo & 2.0 & 0.001 & 1.0 & 0.00027 & 0.00027 \\
\hline 47 & $\mathrm{Ag}_{\mathbf{g}}$ & 0.0001 & & 0.0001 & 0.00009 & 0.00009 \\
\hline 48 & Cd & 0.0002 & & 0.0001 & 0.0001 & 0.0001 \\
\hline 50 & $\mathrm{Sn}$ & 0.005 & & 0.003 & 0.003 & 0.003 \\
\hline 51 & sb & 0.001 & & 0.301 & 0.0005 & 0.0005 \\
\hline 56 & $\mathrm{Ba}$ & 0.001 & & 0.001 & 0.0002 & 0.0002 \\
\hline 65 & Ib & 0.001 & & 0.0005 & 0.0002 & 0.0002 \\
\hline 73 & $\mathbf{T a}$ & 0.01 & 0.001 & 0.001 & 0.0004 & 0.0004 \\
\hline 74 & $w$ & 0.05 & 0.0002 & 0.5 & 2.50 & 0.01 \\
\hline 77 & Ir & 0.001 & & 0.0005 & 0.0002 & 0.0002 \\
\hline 82 & $\mathrm{~Pb}$ & 0.001 & & 0.001 & 0.0005 & 0.0005 \\
\hline 83 & $\mathrm{Bi}$ & 0.001 & & 0.001 & 0.0002 & 0.0002 \\
\hline
\end{tabular}


Table [-B. Elemental compositions.

\begin{tabular}{|c|c|c|c|c|c|c|c|c|}
\hline \multirow[b]{2}{*}{$z-1$} & \multirow[b]{2}{*}{ Element } & \multicolumn{7}{|c|}{ Breeding/multiplier materials } \\
\hline & & $\begin{array}{l}\mathrm{Li} \\
(u+z)\end{array}$ & $\begin{array}{l}\text { FLIBE } \\
\text { (utz) }\end{array}$ & $\begin{array}{c}17 \mathrm{Li83Pb} \\
(u \in Z)\end{array}$ & $\begin{array}{l}\text { Nitrate } \\
\text { salt } \\
\text { (utz) }\end{array}$ & $\begin{array}{l}\operatorname{Li}_{2} O \\
(w t z)\end{array}$ & $\begin{array}{r}\operatorname{LiA10} 2 \\
(u+x)\end{array}$ & $\begin{array}{c}\text { Be } \\
(\text { wez) }\end{array}$ \\
\hline 1 & $\mathrm{Li}$ & 99.9 & 8.60 & 0.68 & & & 10.3 & 0.0003 \\
\hline 4 & $\mathrm{Be}$ & & 13.0 & 0.001 & & & 0.001 & 99.0 \\
\hline 5 & $\mathrm{~B}$ & & & 0.001 & & & 0.001 & 0.0002 \\
\hline 6 & C & 0.001 & & & & & & 0.10 \\
\hline 7 & $\mathbf{N}$ & 0.005 & & 0.001 & 15.0 & & & 0.03 \\
\hline 8 & 0 & & & 0.026 & 51.6 & & 48.6 & 0.7 \\
\hline 9 & $\mathbf{F}$ & & 78.4 & & & & & \\
\hline 11 & $\mathbf{N a}$ & 0.03 & & 0.01 & 12.3 & 0.005 & 0.005 & \\
\hline 12 & $\mathrm{Mg}$ & & & 0.001 & & & & 0.08 \\
\hline 13 & Al & & & 0.005 & & 0.002 & 40.9 & 0.09 \\
\hline 14 & $\mathrm{Si}$ & 0.008 & & 0.001 & & 0.001 & & 0.06 \\
\hline 15 & $P$ & & & 0.05 & & & 0.05 & \\
\hline 16 & $\mathbf{s}$ & & 0.0005 & 0.03 & & & & \\
\hline 17 & $\mathrm{Cl}$ & 0.004 & & 0.002 & & 0.01 & 0.01 & \\
\hline 19 & $\mathrm{~K}$ & 0.02 & & 0.03 & 21.0 & 0.037 & 0.05 & \\
\hline 20 & $\mathrm{Ca}$ & 0.03 & & 0.01 & & 0.021 & 0.003 & 0.02 \\
\hline 22 & $\mathbf{T} \mathbf{i}$ & & & 0.003 & & & 0.003 & \\
\hline 23 & v & 0.0003 & & 0.003 & & & 0.003 & \\
\hline 24 & $\mathrm{C} \mathbf{r}$ & 0.0002 & 0.0019 & 0.002 & 0.08 & & 0.003 & 0.01 \\
\hline 25 & $M n$ & & & 0,001 & & 0.002 & 0.001 & 0.015 \\
\hline 26 & $\mathrm{Fe}$ & 0.001 & 0.0166 & 0.01 & 0.005 & 0.010 & 0.003 & 0.06 \\
\hline 27 & $\mathrm{Co}$ & & & 0.003 & 0.00001 & & 0.003 & 0.0005 \\
\hline 28 & $\mathrm{Ni}$ & & 0.0026 & 0.001 & 0.001 & 0.002 & 0.002 & 0.03 \\
\hline 29 & $\mathrm{Cu}$ & & & 0.001 & & 0.0006 & 0.001 & 0.01 \\
\hline 30 & $2 n$ & & & 0.05 & & & 0.05 & 0.02 \\
\hline 33 & $\mathrm{As}$ & & & 0.03 & & & 0.05 & \\
\hline $\begin{array}{l}28 \\
40\end{array}$ & $\begin{array}{l}S_{\mathbf{r}} \\
\mathrm{Zr}_{\mathbf{r}}\end{array}$ & & & $\begin{array}{l}0.10 \\
0.03\end{array}$ & & & $\begin{array}{l}0.10 \\
0.01\end{array}$ & \\
\hline 41 & $\mathrm{Nb}$ & & & & 0.0001 & & & \\
\hline 42 & Ho & & & 0.003 & 0.001 & & 0.003 & 0.002 \\
\hline 47 & $\mathrm{Ag}$ & & & 0.001 & & & 0.001 & \\
\hline 48 & Cd & & & 0.005 & & & 0.01 & 0.0002 \\
\hline 50 & $\mathbf{s n}$ & & & 0.001 & & & 0.03 & \\
\hline 51 & Sb & & & 0.003 & & & 0.01 & \\
\hline 56 & $\mathrm{Ba}$ & & & 0.01 & & & 0.01 & \\
\hline 73 & $\mathbf{T a}$ & & & & & & & \\
\hline 74 & $\omega$ & & & & & & & \\
\hline $\begin{array}{l}82 \\
83\end{array}$ & $\begin{array}{l}\mathrm{Pb} \\
\mathrm{Bi}\end{array}$ & & & $\begin{array}{r}99.32 \\
0.01\end{array}$ & & 0.008 & $\begin{array}{l}0.001 \\
0.001\end{array}$ & 0.002 \\
\hline
\end{tabular}


Table II-A. Limics for clang C wastes appropriate for activation wased in fusion and defined in locfrol.

\begin{tabular}{lc}
\hline \multicolumn{1}{c}{ Nuelide } & Limit $\left(\mathrm{Ci} / \mathrm{m}^{3}\right)$ \\
\hline All nuclides vith less than S-year half life & No limit \\
H3 & No limit \\
Co60 & 80 \\
C14 in activated metal & 8 \\
C14 & 7000 \\
Ni63 in activated metal & 700 \\
Ni63 & 220 \\
Ni59 in activated metal & 0.2 \\
Nb94 itl activated metal & 3 \\
Te99 & 7000 \\
Sr90 & 4600 \\
Cs137 & $100(\mathrm{nCi} / \mathrm{g})$ \\
Alpha emicting tranguranic nuclides & \\
\hline vith half lives greater than five years & \\
\hline
\end{tabular}

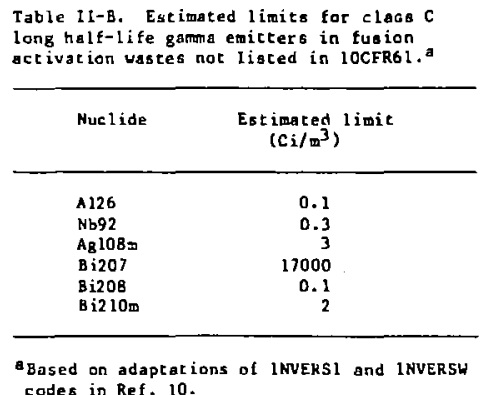

codes in Ref. 10.

Table IIt. Relative rankinge of materials by RMR.

\begin{tabular}{|c|c|c|c|c|c|c|c|}
\hline \multicolumn{8}{|c|}{ Time after shutdown } \\
\hline \multicolumn{2}{|c|}{ I Hour } & \multicolumn{2}{|c|}{1 Day } & \multicolumn{2}{|l|}{10 Y้องุ } & \multicolumn{2}{|c|}{100 Yевтв } \\
\hline Material & $\operatorname{AMR}(\operatorname{mren} / \mathrm{hr})$ & Material & $\operatorname{RHR}($ mrem/hr) & Material & $M R($ mren/hr) & Material & $\operatorname{RHR}(\mathrm{mren} / \mathrm{hr}$ ) \\
\hline TENELON & $9.14 \times 10^{10}$ & $\mathrm{LiAlO}$ & $2.83 \times 10^{10}$ & PCA & $2.30 \times 10^{8}$ & LiAlO, & $2.09 \times 10^{4}$ \\
\hline $\mathrm{LiAlO}_{2}$ & $8.17 \times 10^{10}$ & vcrTi & $1.36 \times 10^{10}$ & Mitrate galt & $4.61 \times 10^{7}$ & HTS & $2.07 \times 10^{4}$ \\
\hline PCA & $3.69 \times 10^{10}$ & TENELON & $1.33 \times 10^{10}$ & HT9 & $4.41 \times 10^{7}$ & $\mathrm{PCA}$ & $9.44 \times 10^{3}$ \\
\hline HodHT9 & $2.93 \times 10^{10}$ & PCA & $1.16 \times 10^{10}$ & TEMELOH & $1.39 \times 10^{7}$ & LiPb & $9.24 \times 10^{3}$ \\
\hline нт9 & $2.89 \times 10^{10}$ & ModHT9 & $4.24 \times 10^{9}$ & ModHT9 & $1.11 \times 10^{7}$ & ModHT 9 & $4.26 \times 10^{2}$ \\
\hline vcrti & $1.93 \times 10^{10}$ & HT9 & $4.17 \times 10^{9}$ & $\mathrm{LiAlO}_{2}$ & $5.36 \times 10^{6}$ & TENELON & $4.22 \times 10^{2}$ \\
\hline Mitrate salt & $8.55 \times 10^{9}$ & Hitrate salc & $=3.25 \times 10^{9}$ & $\mathrm{LiPb}^{2}$ & $4.16 \times 10^{6}$ & vCrTi & $1.83 \times 10^{2}$ \\
\hline De & $4.92 \times 10^{8}$ & He & $1.67 \times 10^{8}$ & Be & $1.26 \times 10^{6}$ & Be & $4.99 \times 10^{1}$ \\
\hline LiFb & $1.42 \times 10^{8}$ & LiPb & $8.85 \times 10^{7}$ & Lithium & $9.13 \times 10^{4}$ & Nitrate oalt & $2.33 \times 10^{1}$ \\
\hline $\mathrm{Li}_{2} \mathrm{O}$ & $2.17 \times 10^{7}$ & lithium & $5.86 \times 10^{6}$ & $\mathrm{Li}_{2} \mathrm{O}$ & $4.44 \times 10^{4}$ & $\mathrm{Li}_{2} \mathrm{O}$ & $1.72 \times 10^{0}$ \\
\hline Lienium & $1.48 \times 10^{7}$ & $\mathrm{Li}_{2} \mathrm{n}$ & $5.53 \times 10^{6}$ & FLtRE & $2.79 \times 10^{4}$ & FLIBE & $2.02 \times 10^{-1}$ \\
\hline FLIBE & $6.06 \times 10^{6}$ & FLIBE & $1.73 \times 10^{6}$ & vCrTi & $6.53 \times 10^{3}$ & Lithium & $1.87 \times 10^{-2}$ \\
\hline
\end{tabular}


Table IV. Major nuclides for high RMR.

\begin{tabular}{|c|c|c|c|c|}
\hline Material & l Hour & 1 Day & 10 Years & 100 Years \\
\hline $\mathbf{P C A}$ & $\begin{array}{l}\operatorname{Mn} 54, \operatorname{Mn} 56 \\
\operatorname{Co58}, C_{060}\end{array}$ & $\begin{array}{l}\operatorname{Mn} 56 \\
\operatorname{Co5} 8, \operatorname{Cos} 0\end{array}$ & $\mathrm{C}_{0} 60$ & $\begin{array}{l}\mathrm{C} 060, \mathrm{Hb} 94 \\
\mathrm{~A}_{\mathrm{B}} 10 \mathrm{Bm}, \mathrm{B} 1207\end{array}$ \\
\hline HT9 & $\mathrm{MnS4}, \mathrm{Hn} 56$ & $\begin{array}{l}\operatorname{Mn} 54 \\
\operatorname{Cos} 5, \operatorname{Cos} 0\end{array}$ & 0060 & Nb94 \\
\hline HodHT9 & $\begin{array}{l}\text { MnS4, MnS6 } \\
\text { W187 }\end{array}$ & $\begin{array}{l}\text { Mn54 } \\
\text { W187, Ta182 }\end{array}$ & $\begin{array}{l}\text { MnS4 } \\
\text { Coso }\end{array}$ & $\begin{array}{l}\text { Co60, } \\
\text { A g } 10894, \text { Bi207 }\end{array}$ \\
\hline TENELON & $\operatorname{Mn} 54, \operatorname{Mn} 56$ & $\mathrm{Mn} 54, \mathrm{Hn} 56$ & $\begin{array}{l}\mathrm{HnS4} \\
\mathrm{CosD}\end{array}$ & $\begin{array}{l}\text { Co60 } \\
\mathrm{Ag} 108 \mathrm{~m}, \mathrm{Bi207}\end{array}$ \\
\hline VLSCrSTi & $5 \times 46,5048$ & $\operatorname{Se} 46, \operatorname{Se} 48$ & $\begin{array}{l}\mathrm{C} 060 \\
\times 42\end{array}$ & $\begin{array}{l}\mathrm{Nb94} \\
\times 42, \text { A } 126\end{array}$ \\
\hline $\operatorname{LiAlO} 2$ & $\mathrm{Na} 24$ & $\mathrm{Na} 24$ & $\operatorname{Co60}$ & $\begin{array}{l}\text { A } 126 \\
\text { Agl08m }\end{array}$ \\
\hline $17 \mathrm{~L} i \mathrm{BPb}$ & $\begin{array}{l}\text { Ag76, Co60 } \\
\mathrm{Na24}, 2 \mathrm{n} 65 \\
\mathrm{Pb203}, \mathrm{Sb} 124 \\
\mathrm{2r89}, \mathrm{Mn} 56 \\
\text { Y89m }\end{array}$ & $\begin{array}{l}\text { As76, Co60 } \\
2 \mathrm{n} 65,56124 \\
\mathrm{Na24}, \mathrm{Zr} 89 \\
\mathrm{Ti202}, \mathrm{Y} 89 \mathrm{~m}\end{array}$ & $\mathrm{Co60}$ & $\begin{array}{l}\text { Agl0Bm } \\
\text { Bi20?, } 8 \mathrm{i208}\end{array}$ \\
\hline $\mathrm{Be}$ & $\begin{array}{l}\mathrm{Na} 24 \\
\mathrm{HnS4}, \mathrm{HnS6}\end{array}$ & $\begin{array}{l}\mathrm{Na} 24 \\
\mathrm{Hn} 54, \operatorname{Co} 58\end{array}$ & Co60 & $\begin{array}{l}\text { A } 126 \\
\text { Co60 }\end{array}$ \\
\hline $\mathrm{Li}_{2} \mathrm{O}$ & $\begin{array}{l}\text { Mn54, Mn56 } \\
\text { Ma24 }\end{array}$ & $\begin{array}{l}\mathrm{MnS4} \\
\mathrm{Na24}, \mathrm{Co5} 8\end{array}$ & $\begin{array}{l}\mathrm{Co60} \\
\mathrm{Na22}\end{array}$ & $\begin{array}{l}\text { Al26, Co60 } \\
\text { Bi207 }\end{array}$ \\
\hline Lithium & $\mathrm{Na} 22, \mathrm{Ha} 4$ & $\mathrm{Na} 22, \mathrm{Ma} 24$ & $\begin{array}{l}\mathrm{He} 22 \\
\mathrm{C} 060\end{array}$ & $\begin{array}{l}K 40 \\
K 42\end{array}$ \\
\hline Nitrate salt & $\begin{array}{l}\mathrm{N} 222, \mathrm{Na} 24 \\
\mathrm{Ar} 4 \mathrm{l}\end{array}$ & $\mathrm{Na} 22, \mathrm{Na} 24$ & $\mathrm{Ha} 22$ & $\begin{array}{l}\mathrm{Nb94} \\
\mathrm{C} 136\end{array}$ \\
\hline FLIBE & $\begin{array}{l}\operatorname{Mn} 54, \operatorname{Mn} 56 \\
\operatorname{Co5} 58\end{array}$ & $\begin{array}{l}\operatorname{Cos} 8, \operatorname{Mn} 54 \\
\operatorname{Co} 60\end{array}$ & Co60 & Co60 \\
\hline
\end{tabular}

Table v. Haste disposal rating at 10 years after shutdawn.

\begin{tabular}{|c|c|c|c|c|c|c|c|c|c|c|c|c|}
\hline \multirow[b]{2}{*}{$\begin{array}{l}\text { Macerial } \\
\text { nuclide }\end{array}$} & \multirow[b]{2}{*}{ HTg } & \multirow[b]{2}{*}{ PCA } & \multirow[b]{2}{*}{$\operatorname{LiAlO} \mathrm{O}_{2}$} & \multicolumn{8}{|c|}{ WDR (dimensionless ratio) } & \multirow[b]{2}{*}{$\mathbf{L i}$} \\
\hline & & & & $\begin{array}{l}\text { Nitrate } \\
\text { salt }\end{array}$ & $\mathrm{LiPb}$ & $V C_{r} T i$ & TENELON & $\begin{array}{l}\text { Hod } \\
\text { HT9 }\end{array}$ & $\mathrm{Be}$ & $\mathrm{Li}_{2} \mathrm{O}$ & FLIBE & \\
\hline $\begin{array}{l}\mathrm{C} 14 \\
\mathrm{Ni} 59 \\
\mathrm{Ni} 63 \\
\mathrm{Nb} 94 \\
\mathrm{Tc} 99\end{array}$ & $\begin{array}{l}1.0 \\
0.5 \\
0.40 \\
477 \\
5.38\end{array}$ & $\begin{array}{c}0.21 \\
2.4 \\
6.6 \\
176 \\
11.0\end{array}$ & $\begin{array}{l}0.02 \\
0.01\end{array}$ & 70.9 & $\begin{array}{l}0.03 \\
0.01 \\
0.10 \\
0.02\end{array}$ & 0.16 & $\begin{array}{l}0.10 \\
0.01 \\
0.46\end{array}$ & $\begin{array}{l}0.02 \\
0.01 \\
0.46\end{array}$ & $\begin{array}{l}0.15 \\
0.01 \\
0.01\end{array}$ & 0.33 & 0.14 & 0.01 \\
\hline Subtotal & 484 & 196 & 0.41 & 71 & 0.16 & 1.48 & 0.57 & 0.49 & 0.17 & 0.33 & 0.24 & 0.01 \\
\hline $\begin{array}{l}\text { A } 126 \\
\text { A } 108 \mathrm{~m} \\
\text { Bi207 } \\
\text { Bi208 }\end{array}$ & $\begin{array}{l}0.11 \\
0.85 \\
0.25\end{array}$ & $\begin{array}{l}0.33 \\
0.86 \\
0.26\end{array}$ & $\begin{array}{l}147 \\
2.8 \\
0.08\end{array}$ & & $\begin{array}{c}0.07 \\
10.6 \\
0.02 \\
13.6\end{array}$ & 0.17 & $\begin{array}{l}0.09 \\
0.77 \\
0.05\end{array}$ & $\begin{array}{l}0.09 \\
0.76 \\
0.05\end{array}$ & 0.23 & 0.01 & & \\
\hline Subtotal & 1.2 & 1.45 & 150 & & 24.3 & 0.17 & 0.91 & 0.90 & 0.23 & 0.01 & & \\
\hline Total & 485 & 198 & 150 & 71 & 24.5 & 1.65 & 1.5 & 1.4 & 0.40 & 0.34 & 0.14 & 0.01 \\
\hline
\end{tabular}


Table VI. Suitability of materialo for near-aurface burial.

\begin{tabular}{|c|c|c|c|}
\hline GDRC 1 & $1<H D B<5$ & w & $O R>5$ \\
\hline Glass $A^{a}$ & $c \operatorname{lasg} \mathrm{c}^{\mathbf{b}}$ & Not suitable & for near-surface burialc \\
\hline Be & V15Cr5Ti & & HTS \\
\hline $\operatorname{li}_{2} \mathrm{O}$ & HodHT9 & & PCA \\
\hline Lithium & TENELON & & $\mathrm{LIAlO}_{2}$ \\
\hline \multirow[t]{2}{*}{ ELIBE } & & & $17 \mathrm{Li} 83 \mathrm{~Pb}$ \\
\hline & & & Nitrate salt \\
\hline
\end{tabular}

aRequires only packaging to provide phyicel, mechanical, and chemicel stability for near-gurface burial.

buill be diluted ta Clas $C$ by normal mixing with inert and lese active merials frod reactor during vate packaging. Require packaging for physical, mechanical, and chemical stability for near-surface burial.

EWDR and totel quantities of material make reduction to clase $\mathcal{C}$ by dilution impractical. Processing is required to remove high activity nuclides to bring the remaining material to Clas $c$ for packaging for nearmartace burial. The high activity nuclides require at least a "hot" waste facility or perhaps even deep geological burial.

Table VII. Major nuclides preventing near-auface burial.

\begin{tabular}{lll}
\hline Material & $\begin{array}{c}\text { Major } \\
\text { nuclides }\end{array}$ & $\begin{array}{c}\text { Source } \\
\text { elements }\end{array}$ \\
\hline HT9 & Nb94 & $\mathrm{Nb}, \mathrm{Ho}$ \\
& $\mathrm{Tc99}$ & $\mathrm{Mo}, \mathrm{No}$ \\
PCA & $\mathrm{Nb94}$ & $\mathrm{Nb}, \mathrm{Mo}$ \\
& $\mathrm{Tc99}$ & $\mathrm{Al}$ \\
LiA10 & $\mathrm{Al26}$ & $\mathrm{Bi}, \mathrm{Pb}$ \\
17Li83Pb & $\mathrm{Bi208}$ & $\mathrm{Ag}$ \\
& $\mathrm{Ag} 108 \mathrm{ab}$ & $\mathrm{N}$
\end{tabular}

Table VIII. Alpha emitter concentrations for Lipb.

\begin{tabular}{lll}
\hline Nuclide & \multicolumn{2}{c}{ Cancentration $(\mathrm{nCi} / \mathrm{g})$} \\
\cline { 2 - 3 } & Shutdown & \multicolumn{1}{c}{$10 \mathrm{ye} \mathrm{after}$ shutdown } \\
\hline Pb210 & $1.31 \times 10^{\mathrm{l}}$ & $9.56 \times 10^{0}$ \\
Bi210 & $6.55 \times 10^{5}$ & $1.82 \times 10^{1}$ \\
Bi210m & $3.25 \times 10^{-1}$ & $3.25 \times 10^{-1}$ \\
Po210 & $4.93 \times 10^{5}$ & $1.83 \times 10^{0}$ \\
\hline
\end{tabular}

